\title{
The grammaticalization of Mainland Scandinavian MAYBE ${ }^{1}$ \\ Karin Beijering \\ University of Groningen
}

\begin{abstract}
This paper is concerned with epistemic adverbs of the MAYBE-type (deriving from a modal auxiliary 'can' or 'may' + a main verb meaning 'happen' or 'be') in Mainland Scandinavian. MAYBE is a sentence adverb that occurs in V2 and non-V2 clauses. In non-V2 clauses, MAYBE is the first constituent followed by a clause which has subordinate word order. In V2 clauses, MAYBE can be any constituent except the second one. Swedish MAYBE may also occur in non-V2 clauses in which it is the second constituent, i.e., MAYBE occupies the position of the finite verb. This clause type is not available in Norwegian and Danish. I will outline the etymology, development and grammaticalization path of Mainland Scandinavian MAYBE and argue that the coexistence of V2 and non-V2 clauses with MAYBE is due to different stages of grammaticalization in the development of MAYBE.
\end{abstract}

\section{Introduction}

There are basically two types of modal adverbs that express epistemic modality in the Mainland Scandinavian languages. Derivations from adjectives (1a) and various types of univerbations, i.e. the merger of two or more words into one (1b). In this paper, all examples are from Swedish unless stated otherwise.

a. visst, säkert 'certainly', möjligen 'possibly', troligen 'probably'

b. kanske, kanhända, måhända 'maybe / perhaps'

This paper is concerned with epistemic adverbs of the type exemplified in (1b) (i.e. univerbations of a modal auxiliary 'can' or 'may' + a main verb meaning 'happen' or 'be') in Mainland Scandinavian, i.e., Norwegian kanskje, Swedish kanske and Danish måske ${ }^{2}$. These epistemic adverbs all mean 'maybe' and are referred to as MAYBE whenever all three of them are discussed together.

Swedish kanske is an epistemic adverb with special syntactic status (cf. Andréasson 2002; Platzack 1998; Teleman 1974) because it does not always adhere to standard Swedish word order in declarative main clauses (see Platzack 1998, 85 for an overview of all possible word orders in Swedish). That is, kanske may violate the Verb Second principle. Verb Second (henceforth V2) is a property of declarative main clauses, as in (2a) and Wh-questions, as in (2b), which is found in all Germanic languages except English. In V2 languages the finite verb is the second constituent in a declarative main clause, i.e. only one constituent may precede the finite verb.

(2) a. Olle kommer imorgon.

b. Olle har besökt

Imorgon kommer $\begin{aligned} & \text { Olle. } \\ & \text { Tomorrow comes }\end{aligned}$ Olle.
Vem har Olle besökt?
Who has Olle visited?

\footnotetext{
${ }^{1}$ I would like to thank Muriel Norde for comments and suggestions on earlier versions of this paper. The suggestions by two anonymous reviewers for BeLLS have also helped me to improve this paper.

2 The adverb kanske does exist in Danish but is archaic. It occurs very infrequently, only 34 times in KorpusDK. For example: -Det er kanske frøken Haarlev. 'It is maybe Miss Haarlev.'
} 
In Mainland Scandinavian, declarative main clauses with a subject as the first constituent (3a) seem to have the same word order as subordinate clauses (3b). The difference in word order between main and subordinate clauses can be made visible by the position of sentence adverbs or a negation marker (Holmberg and Platzack 1995, 45). In declarative main clauses the finite verb occurs in second position followed by the negation marker inte 'not' $(3 \mathrm{c})$. In subordinate clauses, the finite verb occurs after the negation marker inte ( $3 \mathrm{~d})$.

\begin{tabular}{|c|c|c|c|}
\hline $\begin{array}{l}\text { Olle } \\
\text { Olle }\end{array}$ & $\begin{array}{l}\text { kommer } \\
\text { comes }\end{array}$ & $\begin{array}{l}\text { i dag. } \\
\text { today. }\end{array}$ & \\
\hline $\begin{array}{l}\text { b. } \\
\text { that }\end{array}$ & $\begin{array}{l}\text { Olle } \\
\text { Olle }\end{array}$ & $\begin{array}{l}\text { kommer } \\
\text { comes }\end{array}$ & $\begin{array}{l}i \text { dag. } \\
\text { today. }\end{array}$ \\
\hline $\begin{array}{l}\text { Olle } \\
\text { Olle }\end{array}$ & $\begin{array}{l}\text { kommer } \\
\text { comes }\end{array}$ & $\begin{array}{l}\text { inte } \\
\text { not }\end{array}$ & $\begin{array}{l}\text { i dag. } \\
\text { today. }\end{array}$ \\
\hline $\begin{array}{l}\text { att } \\
\text { that }\end{array}$ & $\begin{array}{l}\text { Olle } \\
\text { Olle }\end{array}$ & $\begin{array}{l}\text { inte } \\
\text { not }\end{array}$ & $\begin{array}{l}\text { kommer } \\
\text { comes }\end{array}$ \\
\hline
\end{tabular}

It is in declarative main clauses that kanske may violate the rules of Swedish word order. As the examples in (4a-d) show, both V2 $(4 \mathrm{a}, \mathrm{b})$ and non-V2 $(4 \mathrm{c}, \mathrm{d})$ word order are possible in declarative main clauses with kanske, see section 4.4 for an explanation. Note that other sentence adverbs cannot occur in non-V2 clauses $^{3}(4 \mathrm{e}, \mathrm{f})$, but focus adverbs like for example också 'also' or bara 'only' can ${ }^{4}(4 \mathrm{~g}, \mathrm{~h})$.

\begin{tabular}{|c|c|c|c|c|}
\hline $\begin{array}{l}\text { a. Olle } \\
\text { Olle }\end{array}$ & $\begin{array}{l}\text { har } \\
\text { has }\end{array}$ & $\begin{array}{l}\text { kanske } \\
\text { maybe }\end{array}$ & $\begin{array}{l}\text { läst } \\
\text { read }\end{array}$ & $\begin{array}{l}\text { boken. } \\
\text { book-the. }\end{array}$ \\
\hline $\begin{array}{l}\text { b. Kanske } \\
\text { Maybe }\end{array}$ & $\begin{array}{l}\text { har } \\
\text { has }\end{array}$ & $\begin{array}{l}\text { Olle } \\
\text { Olle }\end{array}$ & $\begin{array}{l}\text { läst } \\
\text { read }\end{array}$ & $\begin{array}{l}\text { boken. } \\
\text { book-the. }\end{array}$ \\
\hline $\begin{array}{l}\text { Olle } \\
\text { Olle }\end{array}$ & $\begin{array}{l}\text { kanske } \\
\text { maybe }\end{array}$ & $\begin{array}{l}\text { har } \\
\text { has }\end{array}$ & $\begin{array}{l}\text { läst } \\
\text { read }\end{array}$ & $\begin{array}{l}\text { boken. } \\
\text { book-the. }\end{array}$ \\
\hline $\begin{array}{l}\text { Kanske } \\
\text { Maybe }\end{array}$ & $\begin{array}{l}\text { Olle } \\
\text { Olle }\end{array}$ & $\begin{array}{l}\text { har } \\
\text { has }\end{array}$ & $\begin{array}{l}\text { läst } \\
\text { read }\end{array}$ & $\begin{array}{l}\text { boken. } \\
\text { book-the. }\end{array}$ \\
\hline $\begin{array}{l}\text { e. } \begin{array}{l}\text { *lle } \\
\text { Olle }\end{array}\end{array}$ & $\begin{array}{l}\text { förmodligen } \\
\text { supposedly }\end{array}$ & $\begin{array}{l}\text { har } \\
\text { has }\end{array}$ & $\begin{array}{l}\text { läst } \\
\text { read }\end{array}$ & $\begin{array}{l}\text { boken. } \\
\text { book-the. }\end{array}$ \\
\hline 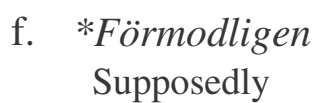 & $\begin{array}{l}\text { Olle } \\
\text { Olle }\end{array}$ & $\begin{array}{l}\text { har } \\
\text { has }\end{array}$ & $\begin{array}{l}\text { läst } \\
\text { read }\end{array}$ & $\begin{array}{l}\text { boken. } \\
\text { book-the. }\end{array}$ \\
\hline $\begin{array}{l}\text { g. } \begin{array}{l}\text { Olle } \\
\text { Olle }\end{array}\end{array}$ & $\begin{array}{l}\text { bara } \\
\text { only }\end{array}$ & $\begin{array}{l}\text { läser } \\
\text { reads }\end{array}$ & $\begin{array}{l}\text { böcker. } \\
\text { books. }\end{array}$ & \\
\hline $\begin{array}{l}\text { Också } \\
\text { Also }\end{array}$ & $\begin{array}{l}\text { Olle } \\
\text { Olle }\end{array}$ & $\begin{array}{l}\text { har } \\
\text { has }\end{array}$ & $\begin{array}{l}\text { läst } \\
\text { read }\end{array}$ & $\begin{array}{l}\text { boken } \\
\text { book-the. }\end{array}$ \\
\hline
\end{tabular}

\footnotetext{
${ }^{3}$ Exceptions are the synonymous adverbs kanhända, måhända and törhända (archaic), all meaning 'maybe', which may occur in clauses like (4d): Kanhända Olle har läst boken.

${ }^{4}$ Kanske cannot be analyzed as a focus adverb, despite the apparent similarities in (4c, d, g, h). The most important difference is that kanske as a sentence adverb has scope over the entire clause whereas focus adverbs apply to one constituent only, they are adjuncts. Cf. [Kanske [Olle har läst boken.] versus [Också Olle] har läst boken.]. Unlike focus adverbs, kanske can occur on its own, for example as an answer to a question. A: Ska du på konsert ikväll? 'Are you going to the concert tonight?' B: Kanske 'Maybe'. Here it would not be possible to answer with också 'also' or bara 'only'. A more detailed discussion of the status of focus adverbs in relation to kanske goes beyond the scope of this paper.
} 
Since Swedish kanske may violate the V2 principle, it is interesting to see whether its Mainland Scandinavian cognates, Norwegian kanskje and Danish måske, show the same syntactic behaviour. That is, are the word orders in (4a-d) also grammatical in Danish and Norwegian? The following research question, as stated in (5), will be addressed:

\begin{abstract}
What are the differences and similarities between the Mainland Scandinavian languages with respect to the distribution, development and grammaticalization of the epistemic adverb MAYBE? More specifically, do the Mainland Scandinavian languages differ in the degree of grammaticalization for MAYBE?
\end{abstract}

The number of syntactic positions for a linguistic item is a useful criterion in determining the degree of grammaticalization. When comparing the degree of multipositionality of MAYBE, one might find different stages of grammaticalization. That is, MAYBE can be more grammaticalized (=less syntactic freedom) in one language than in another (=more syntactic freedom). Corpus data of MAYBE is analyzed and compared for Danish, Norwegian and Swedish in order to determine the number of syntactic positions and the degree of grammaticalization for MAYBE in the Mainland Scandinavian languages.

I will outline the etymology, development and grammaticalization path of Mainland Scandinavian MAYBE and show that the coexistence of V2 and non-V2 clauses with MAYBE is due to different stages within one and the same grammaticalization process instead of separate grammaticalization paths resulting in different syntactic variants of MAYBE as suggested by Andréasson $(2002,46)$ and Lundin (1997).

\title{
2. Sources and method
}

The Swedish data are the results of a corpus investigation on the number of syntactic positions for Swedish kanske carried out by Andréasson (2002). Andréasson's study is based on a random sample of 836 sentences, taken from Språkbankens konkordanser ${ }^{5}$. This corpus contains a subset of modern and historical online corpora and includes texts from various sources: newspapers, literature, non-specialist literature, government debates, law texts and historical texts. Andréasson used the subcorpora Press 98 (P98) and Bonniersromaner II (RII) for her study of kanske. $P 98$ contains text from Swedish newspapers. This corpus consists of 9.239.336 words (tokens) of which 390.265 different words (types). RII is a corpus that contains 60 Swedish novels that are published by Bonniers publishing company in the years 1980 and 1981. This corpus consists of 3.715.690 tokens of which 155.380 are types.

In order to see whether Danish måske and Norwegian kanskje occur in both V2 and non-V2 clauses, I carried out replication studies after Andréasson (2002). The Norwegian and Danish data consist of random samples of 1000 sentences containing kanskje and måske taken from modern online corpora. The Norwegian data is collected from Norsk Aviskorpus ${ }^{6}$. This modern dynamic text corpus consists of newspaper texts from 1998 up to now. Texts from various types of newspapers are part of the corpus: tabloids, broadsheets, national and regional newspapers as well as general, business and financial newspapers. The corpus contains circa 640 million words and approximately 200.000 to 250.000 words of running text are being added to the corpus each day.

The Danish data is selected from Korpus $D K^{7}$, which is a modern online corpus of Danish texts from different sources and genres, with a total of 56 million words. The texts were collected between the years 1990 and 2000. The corpus consists of two subcorpora: Korpus 2000 which consists of texts from the period 1998 to 2002 and Korpus 90 which

\footnotetext{
${ }^{5} \mathrm{http}: / /$ spraakbanken.gu.se/konk/

${ }^{6} \mathrm{http}: / /$ avis.uib.no/

${ }^{7} \mathrm{http}: / /$ ordnet.dk/korpusdk
} 
consists of texts from the period 1983 to 1992 . KorpusDK is mainly designed for linguistic analysis with the particular aim to identify recent developments in the Danish language. The corpora are comparable in the sense that they all contain newspaper texts, but Andréasson's data and KorpusDK contain literary texts as well, which makes the Norwegian corpus less comparable to the Danish and Swedish corpora.

The method for the corpus study of Danish and Norwegian MAYBE is based on Andréasson's (2002) study of Swedish kanske. Only declarative main clauses are considered because it is only in these structures that kanske may violate the V2 principle. Andréasson lists nine types of declarative main clauses containing kanske. These all represent possible word orders for declarative main clauses in which kanske can occur. The Swedish data are analyzed and classified according to these nine declarative main clause types. Interrogative clauses, subordinate clauses, clauses without finite verb, fragmented clauses, clauses in which kanske does not function as sentence adverb (but as a modifying adverb ${ }^{8}$ ) and combinations of a modal auxiliary and a main verb with referential subject (det kan ske att 'it can / may happen') have been excluded.

The same nine declarative main clause types as distinguished by Andréasson (2002, 9), listed in (6), are used to analyze and classify the data in the Norwegian and Danish replication studies. The subscripts $\mathrm{S}$ stands for subject, $\mathrm{F}$ for finite verb, $\mathrm{O}$ for object or predicate, $\mathrm{K}$ for kanske, a for att 'that' and A for various types of adverbs or adjuncts. These nine clause types can be subsumed under three basis clause types. The first clause type are non-V2 clauses with kanske as the first constituent, the subtypes are $\mathrm{KS}$ and $\mathrm{KaS}^{9}$ clauses. The second clause type are V2 clauses. These can have a subject, object or various types of adverbs (including kanske) or adjuncts as the first constituent. The subtypes are represented by SF, KF, OF and AF clauses. The third clause type are non-V2 clauses that have kanske as its second constituent. These can also have a subject, object or various types of adverbs or adjuncts as the first constituent. Subtypes of this clause type are SK, OK and AK clauses. See section 4.4 and 5 for a more detailed discussion of the different clause types.

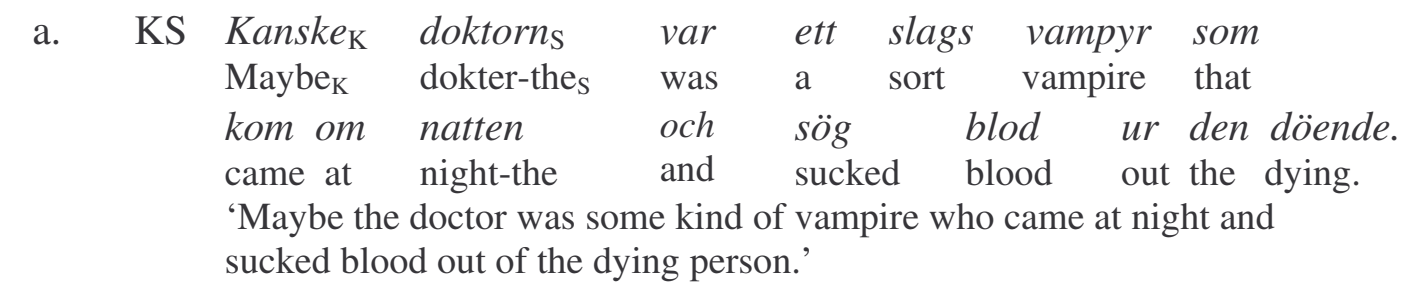

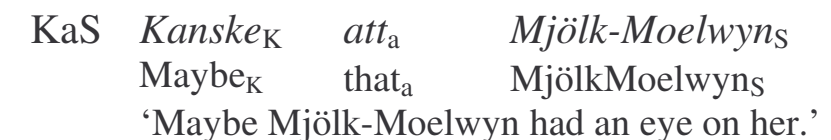

hade ögonen had eyes-the på henne 'Maybe Mjölk-Moelwyn had an eye on her.'

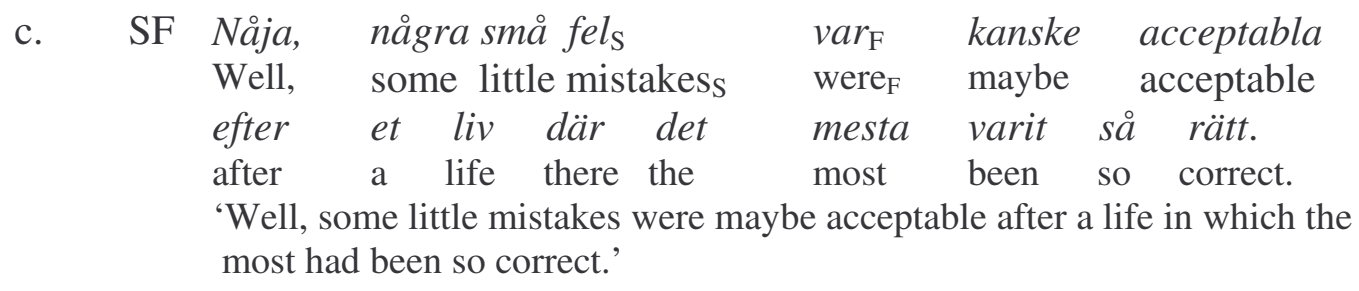

\footnotetext{
${ }^{8}$ For example: Docenterna har gjort den kanske mest klassiska festivalfyllelåten genom tiderna. 'The teachers have done the maybe most classic festival drinking song of all times' (Andréasson 2002, 7).

${ }^{9}$ The KaS clause in (6b) is put in brackets because it is not part of the random sample. That is, examples are obtained by means of a separate search procedure with the aim to find KaS clauses only.
} 


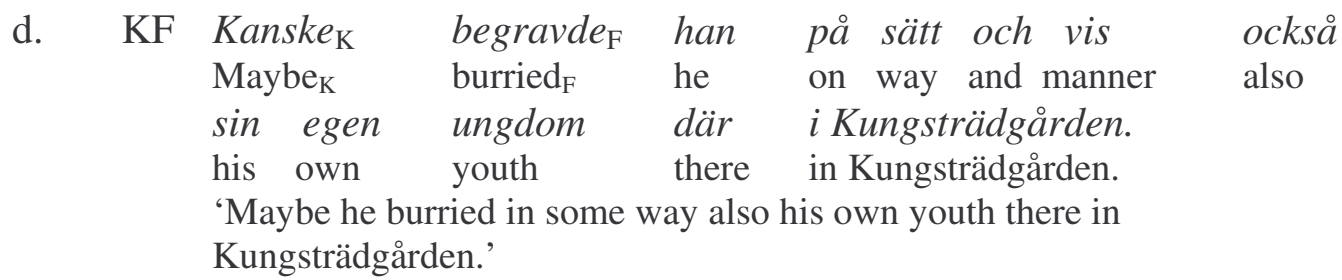

$\begin{array}{llllll}\text { e. OF Men } & \text { Lise Maria }_{\mathrm{O}} & \text { kan }_{\mathrm{F}} & \text { jag } & \text { kanske lite hjälpa } & \text { sen } \\ \text { Ban }_{\mathrm{F}} & \text { I } & \text { Lise Maria } & & \text { maybe bit help afterwards. }\end{array}$ 'But maybe I can help Lise Maria a little bit afterwards.'

f. $\quad \mathrm{AF}$ Innan jag går vidare A $_{\mathrm{A}} \mathrm{F}_{\mathrm{F}}$ det kanske att jag säger Before I go further ${ }_{\mathrm{A}}$ is $\mathrm{F}_{\mathrm{F}}$ it maybe that $\mathrm{I}$ say några ord om meg själv. some words about my self.

'Maybe it is good that I tell something about myself before I continue.'

g. $\quad \mathrm{SK} V i_{\mathrm{S}}$ kanske $_{\mathrm{K}}$ borde lägga Brita

$\mathrm{We}_{\mathrm{S}}$ maybe $_{\mathrm{K}}$ should lay Brita

lite mer bekvämt förresten.

little more comfortable anyway.

'Anyway, maybe we should lay Brita a little more comfortable.'

h. $\mathrm{OK}$-Vad jag tycker är humanitära skäl - $_{\mathrm{O}}$ anske $e_{\mathrm{K}}$ inte

-What I think are humanitarian grounds maybe $_{\mathrm{K}}$ not min kollega håller med om, vi är ju inga robotar. my colleague agrees with on, we are sure no robots.

'How I see humanitarian grounds, my colleague maybe does not agree on, after all we are no robots.'

i. $\mathrm{AK} N u$ när vi är tre man $_{\mathrm{A}}$ kanske $_{\mathrm{K}}$ vi skulle Now when we are three $\operatorname{man}_{\mathrm{A}}$ maybe $_{\mathrm{K}}$ we could kunna ta och palla upp bilen igen. can take and lift up car-the again.

'Now that we are three, maybe we can lift up the car again.'

\section{Etymology of MAYBE}

In the Scandinavian languages MAYBE derives from a verb phrase det kan / må ske att 'it can / may happen that' (cf. Swedish kanske, Norwegian kanskje, Danish måske, Faroese kanska and Icelandic kannski). These adverbs belong to a special class of linguistic elements called Satzwörter, literally 'clausal words' Lindqvist (1961), Wessén (1968). These are words that have developed out of phrases. Examples are kanske and its synonyms kanhända, måhända, törhända (< (det) kan / må / tör hända (att) 'it can / may / must happen that'), English maybe ( $<$ it may be that), French peut-être (< puet estre que 'can be that'), Latin forsitan $(<$ fors sit an 'chance be that') and Dutch misschien (<tmachschien 'it may happen'). Also in Slavonic languages there are adverbs of this type, with the stem moć 'can' as its core. Russian has the forms mozjet byt' or byt' mozjet (literally can ${ }_{3 \mathrm{SG}}$ be) and Bulgarian mozje bi. The West Slavonic languages Czech, Slovak and Polish have respectively the forms možna, možno and może. Serbo-Croatian has the resembling form možda (Ramat and Ricca 1998). MAYBE as a clausal word can be regarded as a (univerbated) finite verb phrase without a subject. 
Various etymologies have been proposed for kanske but its true origin is still uncertain. The intriguing question is whether kanske is a loan translation or part of a cross-linguistically regular grammaticalization path. In this section, I will discuss both possibilities. Wessén (1968) and Hellquist $(1939,441)$, inter alia, take the Old Swedish ${ }^{10}$ adverb maxan as a starting point for the etymology of Modern Swedish kanske. The meaning of this word was 'almost, nearly, approximately' and occasionally it occurred in the sense of 'may be, may happen' (Wessén 1968, 1). What maxan and kanske have in common, according to Hellquist and Wessén, is the connection to the Middle Low German ${ }^{11}$ verb phrase mach schên 'may happen'. Maxan is a Middle Low German loan word that is derived from this verb phrase (mach schên > maxan). In their view, kanske has presumably developed after the model of mach schên, in which case it would be a loan translation.

The question is whether Middle Low German really is the source language for kanske. Given that the same development took place in many European languages, the source language may have been Latin. The Latin formation forsitan may have had strong influence on the development of MAYBE adverbs through translations of literature and other texts, as Latin was the international language in central and Western Europe during the Middle Ages. Closer examination of similar verb phrases and clausal words (e.g. forsitan, mach schên, peut$\hat{e}$ tre) in original texts and translations is needed in order to determine the true origin of kanske, if its origin is a case of borrowing at all.

But instead of being a loan translation, the development of MAYBE may have been a matter of parallel developments in various languages. That is, the development of kanske may be part of a cross-linguistically regular grammaticalization pathway. The univerbation (merger) of a modal form 'can / may' and a main verb meaning 'happen' or 'be', which in turn is derived from a verb phrase '(it) can / may happen' optionally followed by the complementizer 'that' plus a subordinate clause, may have been a process of productive word formation (cf. Brinton and Traugott 2005, 33). At the time when kanske arose, from the Middle Ages onwards, there were many analogous developments of similar verb phrases changing into epistemic adverbs in other European languages (cf. maybe, peut-être, misschien).

Summarizing thus far, kanske can be loan translation of Middle Low German mach schên, Latin forsitan or similar verb phrases in other European languages. It may also be part of a cross-linguistically regular grammaticalization pathway, that is, the univerbation of a modal form 'can' or 'may' and a main verb meaning 'happen' or 'be' may have been a process of productive word formation in various languages. Both scenarios account for the existence of similar epistemic adverbs in European languages. Even though the influence of language contact cannot be excluded, I consider a cross-linguistically regular grammaticalization pathway to be the most plausible etymology for kanske.

The development of Swedish kanske, see section 4, shows that the verb phrase was variable, i.e., both the modal forms and the main verb were interchangeable with synonymous forms, respectively må 'may', tör 'must' and hända 'happen' (cf. kanske's synonyms kanhända, måhända, törhända). Furthermore both kunna 'can / may' and ske 'happen' already existed in Old Swedish (Andréasson 2002,26) which enables univerbation of kan and ske without interference of the Middle Low German verb phrase mach schên or similar verb phrases in other European languages. The verb ske 'happen' is a borrowing from Middle Low German. But since the collocation was variable (cf. univerbations with other modal forms or the verb hända) and Swedish kanske and Norwegian kanskje are not literal translations of mach schên, I consider a loan translation not to be a plausible etymology for kanske.

For Danish måske on the other hand, the link to Middle Low German mach schên is

\footnotetext{
${ }^{10}$ Old Swedish comprises the period between 1225-1525.

${ }^{11}$ Middle Low German comprises the period between 1100-1600.
} 
more plausible, because this adverb contains the modal verb må. It could be that Danish has retained $m a ̊$ in its older meaning "can' ${ }^{12}$. But it could also be that Danish is influenced by West Germanic languages, where the etymological counterparts of $m a ̊$ express deontic and/or epistemic possibility (cf. German mögen 'may', Dutch mogen 'may', English may, but also Danish måtte can mean 'may') rather than deontic and/or epistemic necessity like in the North Germanic languages ${ }^{13}$. Mach schen is also assumed to be the etymological source to måske $\left(\right.$ cf. ODS $\left.^{14}\right)$.

\section{The development of Swedish kanske}

Different stages of development can be distinguished in kanske's transformation from verb phrase to epistemic adverb (Wessén 1968, 15) 15 $^{15}$. At stage I the formal subject det 'it' is more or less obligatory (7a), at stage II the formal subject (det) is no longer part of the verb phrase, but the complementizer att 'that' cannot be omitted (7b), at stage III the complementizer att can be omitted (7c), at stage IV inversion of subject and finite verb is possible, hence V2 clauses (7d), at stage V kanske can occur clause-internally (7e). Nowadays kanske can occur in positions for sentence adverbs (adverbial kanske in $\mathrm{V} 2$ clauses $(7 \mathrm{~d}$, e) and in positions where it is followed by subordinate word order (subordinating kanske in non-V2 clauses), (7b, c). Combinations of a modal auxiliary and a main verb with referential subject as in (7a) are also still possible.

\begin{tabular}{|c|c|c|c|c|c|}
\hline $\begin{array}{l}\text { a. (Det) kan } \\
\text { It can/may }\end{array}$ & $\begin{array}{l}\text { ske } \\
\text { happen }\end{array}$ & $\begin{array}{l}\text { att han } \\
\text { that he }\end{array}$ & $\begin{array}{l}\text { kommer } \\
\text { comes }\end{array}$ & $\begin{array}{l}\text { redan } \\
\text { already }\end{array}$ & $\begin{array}{l}i \text { dag. } \\
\text { today. }\end{array}$ \\
\hline $\begin{array}{l}\text { b. Kanske/kan ske } \\
\text { Maybe }\end{array}$ & $\begin{array}{l}\text { att } \\
\text { that }\end{array}$ & $\begin{array}{l}\text { han } \\
\text { he }\end{array}$ & $\begin{array}{l}\text { kommer } \\
\text { comes }\end{array}$ & $\begin{array}{l}\text { redan } \\
\text { already }\end{array}$ & $\begin{array}{l}\text { i dag. } \\
\text { today. }\end{array}$ \\
\hline $\begin{array}{l}\text { c. Kanske } \\
\text { Maybe }\end{array}$ & $\begin{array}{l}\text { han } \\
\text { he }\end{array}$ & $\begin{array}{l}\text { kommer } \\
\text { comes }\end{array}$ & $\begin{array}{l}\text { redan } \\
\text { already }\end{array}$ & $\begin{array}{l}i \text { dag. } \\
\text { today. }\end{array}$ & \\
\hline $\begin{array}{l}\text { d. Kanske } \\
\text { Maybe }\end{array}$ & $\begin{array}{l}\text { kommer } \\
\text { comes }\end{array}$ & $\begin{array}{l}\text { han } \\
\text { he }\end{array}$ & $\begin{array}{l}\text { redan } \\
\text { already }\end{array}$ & $\begin{array}{l}i \text { dag. } \\
\text { today. }\end{array}$ & \\
\hline $\begin{array}{l}\text { e. Han } \\
\mathrm{He}\end{array}$ & $\begin{array}{l}\text { kommer } \\
\text { comes }\end{array}$ & $\begin{array}{l}\text { kanske } \\
\text { maybe }\end{array}$ & $\begin{array}{l}\text { redan } \\
\text { already }\end{array}$ & $\begin{array}{l}i \text { dag. } \\
\text { today. }\end{array}$ & \\
\hline
\end{tabular}

\subsection{Kanske in the $16^{\text {th }}$ century}

According to Svenska Akademiens Ordbok (The dictionary of the Swedish Academy), the first written occurrences of kanske date from the $16^{\text {th }}$ century, see example (8a) from Gustav Vasa's Bible (1541). Up to the year 1700, kanske could be written as two separate words (8a) or a univerbated word (8b). Both examples are taken from Andréasson $(2002,20)$.

$$
\begin{aligned}
& \text { a. Kan skee at Ioseph är } \quad \text { oss gramse [...] } \\
& \text { May be that Joseph is }
\end{aligned}
$$

'Maybe Joseph resents us.'

\footnotetext{
${ }^{12}$ Note that måske used to be an epistemic adverb in Swedish as well (cf. Svenska Akademiens Ordbok (The dictionary of the Swedish Academy), http://g3.spraakdata.gu.se/saob/) and that the form må is retained in the synonymous adverb måhända which is now archaic. Moreover, kanske still exists in Danish but is archaic, cf. footnote 2.

${ }^{13}$ Deontic possibility = permission 'you may leave', epistemic possibility = uncertainty 'it may happen', deontic necessity = obligation 'you must leave', epistemic necessity = probability 'he must be home (because the lights are on)'.

${ }^{14}$ Ordbog over det Danske Sprog (Dictionary of the Danish Language), http://ordnet.dk/

${ }^{15}$ For the sake of clarity, the developmental stages are exemplified with Modern Swedish equivalents of the older stages.
} 

b. Swarade Sigfried kanskee du vill öfwerfalla mig
Answered Sigfried: maybe you want attack me
nu som förr.
now like before.
'Sigfried answered: maybe you want to attack me like before.'

In the $16^{\text {th }}$ century, the non-V2 clause types in (7a-c) were most frequent and kanske was mostly written as two separate words. Both the formal subject det 'it' and the complementizer att 'that' were optional.

\subsection{Kanske in the $17^{\text {th }}$ century}

From the $17^{\text {th }}$ century onwards, the formal subject det 'it' was no longer part of the verb phrase and the use of the complementizer att 'that' decreased as well. Furthermore, it became more common to write kanske as one word instead of two separate words. The loss of the formal subject and optional complementizer and the fact that kanske was more and more written as one word enabled its reanalysis from verb phrase to sentence adverb. The reanalyzed verb phrase without formal subject and complementizer, kan ske or kanske, could now occur in positions for sentence adverbs in V2 clauses, see the examples in (9). All examples are taken from Andréasson $(2002,29)$.

$$
\begin{aligned}
& \text { a. Jagh täncker, kan skie, thet kommer then dag } \\
& \text { I think, may happen, it comes the day } \\
& \text { min hustroo, hon önskar, hon woro } i \text { werlden eij till. } \\
& \text { my wife, she wishes, she were in world-the not more. } \\
& \text { 'I think, maybe, there comes a day that my wife wishes she would not be in } \\
& \text { the this world anymore.' } \\
& \text { b. Wille önska at iagh snart muntligen finge tala med min } \\
& \text { Would wish that I soon verbally get talk with my } \\
& \text { kliäre] b[ror] så kunde kanske finnas några particuliersaker } \\
& \text { beloved brother, so could maybe be some private matters } \\
& \text { att omtala. } \\
& \text { to discuss. } \\
& \text { 'I would wish that I soon will be able to talk to my beloved brother, maybe } \\
& \text { there will be some private matters to be discussed.' } \\
& \text { c. Fördij kanskee blir iagh inthet här så länge, } \\
& \text { Because maybe stay I not here so long, } \\
& \text { om thett så Continuera will. } \\
& \text { if this so continue will. } \\
& \text { 'Because maybe I will not stay here so long if it continues like this.' } \\
& \text { d. Kanskie skyndar du dig siälf din ägen död. } \\
& \text { Maybe hurry you your self your own death. } \\
& \text { 'Maybe you precipitate your own death.' }
\end{aligned}
$$

\subsection{Kanske in the $18^{\text {th }}$ and $19^{\text {th }}$ century}

From the $18^{\text {th }}$ century onwards, kanske occurs more and more in positions for sentence adverbs. At the end of the $18^{\text {th }}$ century, a new clause type emerges that violates the V2 principle. In these clauses, kanske is the second constituent followed by subordinate word order. Note that this clause type is not mentioned in Wessén's description of the development of kanske in (7). The first occurrences of this clause type are found in the work of the Swedish poet and composer Carl Michael Bellman (1740-1795), (10a, b). The use of this clause type strongly increased in the work of the Swedish writer and dramatist August Strindberg (1849- 
1912). Literary language may be freer and allow for more syntactic variation than ordinary language use, which may have facilitated the rise of this clause type. At the end of the 20th century this structure is well established in the Swedish language. The examples are taken from Andréasson $(2002,31)$.
a. Den Frågan kanske confunderar.
This question maybe confuses.
'This question may be confusing.'
b. Abel kanske ville råda.
Abel maybe would advice.
'Maybe Abel would advice.'

Andréasson $(2002,31)$ shows how this clause type could have developed by reconstructing an older stage of AK clauses (11a), (11b) is the reconstructed example. In AK clauses, it is possible to paraphrase kanske (kan skie in (11a)) as verb phrase (kan det skie att (11b)). Through the course of time, the possibility to paraphrase kanske into a verb phrase was lost, but kanske could still occur in this non-canonical position for sentence adverbs. The other subtypes of clause type III (SK and OK clauses) could have developed by analogy with AK clauses.

$$
\begin{aligned}
& \text { a. och om jag det än woro, } \\
& \text { and if I it anyway were, } \\
& \text { så kan skie det hulpo intet. } \\
& \text { than may happen it helped nothing. } \\
& \text { 'and if I were that, so maybe it did not help.' } \\
& \text { b. och om jag det än woro, } \\
& \text { and if I it anyway were, } \\
& \text { så kan det skie att det hulpo intet. } \\
& \text { so may it happen that it helped nothing. } \\
& \text { 'and if I were that, so maybe that it did not help.' }
\end{aligned}
$$

\subsection{Kanske from the $20^{\text {th }}$ century onwards}

Nowadays there are three different clause types in which kanske can occur. The first clause type (henceforth clause type I) is a non-V2 clause with kanske as its first constituent followed by a clause which has subordinate word order (12a). In these clauses kanske has retained the subordinating properties of the original verb phrase from which it derived because it is followed by the (c)overt complementizer att 'that' and subordinate word order. It is possible to paraphrase kanske as the original verb phrase det kan ske att (12b) but it is not possible to substitute kanske by synonymous adverbs, for example sannolikt 'probably' (12c). The two subtypes of clause type I are KS and KaS clauses (cf. example (6a, b)).
a. Kanske
Maybe
b. Det kan ske
It can / may happen

$\begin{array}{lll}\text { (att) } & \text { han } & \text { inte } \\ \text { (that) } & \text { he } & \text { not } \\ \text { att } & \text { han } & \text { inte } \\ \text { that } & \text { he } & \text { not } \\ \text { (att) } & \text { han } & \text { inte } \\ \text { (that) } & \text { he } & \text { not }\end{array}$
kommer
i dag.
comes today.
c. *Sannolikt
Probably
kommer idag.
comes today.

kommer idag.
comes today.

The second clause type (henceforth clause type II) is a V2 clause in which kanske can be any constituent except the second one $(13 \mathrm{a}, \mathrm{b})$. In these clauses kanske occurs in positions for sentence adverbs in declarative main clauses with standard word order, i.e. V2 clauses. It is 
not possible to paraphrase kanske as the original verb phrase det kan ske att (13c), but kanske can be substituted by synonymous adverbs, for example sannolikt 'probably' (13d). Subtypes of clause type II are SF, KF, OF and AF clauses (cf. example (6c, d, e, f)).

\begin{tabular}{|c|c|c|c|}
\hline $\begin{array}{l}\text { Han } \\
\text { Olle }\end{array}$ & $\begin{array}{l}\text { kommer } \\
\text { comes }\end{array}$ & $\begin{array}{l}\text { kanske } \\
\text { maybe }\end{array}$ & $\begin{array}{l}\text { inte } \\
\text { not }\end{array}$ \\
\hline b. $\begin{array}{l}\text { Kanske } \\
\text { Maybe }\end{array}$ & $\begin{array}{l}\text { kommer } \\
\text { comes }\end{array}$ & $\begin{array}{l}\text { han } \\
\text { he }\end{array}$ & $\begin{array}{l}\text { inte } \\
\text { not }\end{array}$ \\
\hline $\begin{array}{c}\text { c. }{ }^{* H a n} \\
\mathrm{He}\end{array}$ & $\begin{array}{l}\text { kommer } \\
\text { comes }\end{array}$ & $\begin{array}{l}\text { det kan ske att } \\
\text { it can / may happen that }\end{array}$ & $\begin{array}{l}\text { inte } \\
\text { not }\end{array}$ \\
\hline $\begin{array}{l}\text { d. Han } \\
\mathrm{He}\end{array}$ & $\begin{array}{l}\text { kommer } \\
\text { comes }\end{array}$ & $\begin{array}{l}\text { sannolikt } \\
\text { probably }\end{array}$ & $\begin{array}{l}\text { inte } \\
\text { not }\end{array}$ \\
\hline
\end{tabular}

The third clause type (henceforth clause type III) is a non-V2 clause which has kanske as its second constituent, that is, kanske occupies the position of the finite verb (14a). In these clauses kanske has retained the subordinating properties of the original verb phrase because it is followed by subordinate word order. It is neither possible to paraphrase kanske as the original verb phrase det kan ske att (14b) nor to substitute kanske by synonymous adverbs, for example sannolikt 'probably' (14c). The subtypes of clause type III are SK, OK and AK clauses (cf. example $(6 \mathrm{~g}, \mathrm{~h}, \mathrm{i}))$.

\begin{tabular}{|c|c|c|c|}
\hline $\begin{array}{l}\text { a. Han } \\
\mathrm{He}\end{array}$ & $\begin{array}{l}\text { kanske } \\
\text { maybe }\end{array}$ & $\begin{array}{l}\text { inte } \\
\text { not }\end{array}$ & $\begin{array}{l}\text { kommer } \\
\text { comes }\end{array}$ \\
\hline $\begin{array}{c}\text { b. }{ }^{* H a n} \\
\mathrm{He}\end{array}$ & $\begin{array}{l}\text { det kan ske att } \\
\text { it can / may happen that }\end{array}$ & $\begin{array}{l}\text { inte } \\
\text { not }\end{array}$ & $\begin{array}{l}\text { kommer } \\
\text { comes }\end{array}$ \\
\hline $\begin{array}{c}\text { c. }{ }^{*} \mathrm{Han} \\
\mathrm{He}\end{array}$ & $\begin{array}{l}\text { sannolikt } \\
\text { probably }\end{array}$ & $\begin{array}{l}\text { inte } \\
\text { not }\end{array}$ & $\begin{array}{l}\text { kommer } \\
\text { comes }\end{array}$ \\
\hline
\end{tabular}

To illustrate the differences between the clause types, all three of them are placed in Platzack's scheme for main and subordinate clauses, which is based on Diderichsen's (1946, 186) classical schemes for the analysis of main and subordinate clauses in the Mainland Scandinavian languages (Platzack 1998, 93). Platzack merged Diderichsen's schemes for main and subordinate clauses into one scheme and added the type-field.

The first field in this scheme is the 'foundation', which is the position for the first constituent of a clause. This position can be filled by different elements, e.g. subject, object or various types of adverbs and adjuncts. The second field is called 'type'. In main clauses this position is filled by the finite verb, in subordinate clauses 'type' is filled by an (c)overt complementizer. Clause type I is exemplified in (15a), clause type II in (15b) and clause type III in (15c).

\begin{tabular}{|c|c|c|c|c|c|c|c|c|}
\hline & & foundation & type & $\mathrm{S}$ & $\mathrm{a}$ & $\mathrm{V}$ & $\mathrm{S}$ & A \\
\hline \multirow[t]{2}{*}{$(15$} & \multirow[t]{2}{*}{ a. } & Kanske & (att) & Olle & inte & har sovit & & $i$ natt. \\
\hline & & Maybe & (that) & Olle & not & has slept & & last.night. \\
\hline \multirow{2}{*}{\multicolumn{2}{|c|}{ b. }} & Olle & har & & kanske inte & sovit & & i natt. \\
\hline & & Olle & has & & maybe not & slept & & last.night. \\
\hline \multirow{2}{*}{\multicolumn{2}{|c|}{ c. }} & Olle & kanske & & inte & har sovit & & i natt. \\
\hline & & Olle & maybe & & not & has slept & & last.night. \\
\hline
\end{tabular}


According to Platzack $(1998,89 ; 1999,100)$ kanske is positioned in the type-field in all nonV2 structures, but I think this is only true for type III. In type I, kanske is followed by optional 'that' and subordinate word order, which suggests that it is positioned in the foundation-field and the (c)overt complementizer is positioned in the type-field.

In clause type III kanske is positioned in the type-field, which prevents the finite verb from being placed there. This is reflected in the subordinate word order after kanske. It is not possible that both kanske and the finite verb are in the type-field. A clause like Olle kanske har inte sovit i natt 'Olle maybe has not slept last.night' is ungrammatical (cf. Vikner 1995, 45). Andréasson $(2002,45)$ remarks that in order to position kanske in the type-field it has to be defined differently from other sentence adverbs, as a 'clausal word' or a word with clauselike properties. To allow both finite verbs and the sentence adverb kanske in the type-field would be unsatisfactory.

The reason why Swedish kanske can occupy the position of the finite verb is probably that it has preserved verbal properties. In all syntactic variants, kanske functions as sentence adverb, but it is also a 'clausal word' because it ultimately derives from a finite verb phrase. The subordinating properties of the original finite verb phrase are only retained in the non-V2 structures in which kanske may occur, see section 6.

\section{MAYBE in Danish, Norwegian and Swedish}

In this section I will present the result of my replication studies of Danish and Norwegian MAYBE in declarative main clauses, and contrast them with Andréasson's findings for Swedish. Swedish kanske occurs 5183 times in RII and 5913 times in P98. The random sample consists for $60.4 \%$ of declarative main clauses; $71.1 \%$ of these are V2 clauses. Norwegian kanskje occurs 196.504 times in Norsk Aviskorpus. As many as $78.4 \%$ of the clauses in the random sample are declarative main clauses, $88.8 \%$ of which are V2 clauses. Danish måske occurs 42.067 times in KorpusDK. About half of the clauses in the random sample are declarative main clauses, $52.7 \%$, and these consist almost solely of V2 clauses $98.3 \%$. Clauses that do not adhere to the V2 principle are far less frequent than V2 clauses. Of the Swedish clauses, $28.9 \%$ are non-V2 structures (clause type I (9.5\%) and III (19.4\%)). Only $11.2 \%$ of the Norwegian and $1.7 \%$ of the Danish clauses are non-V2 structures (clause type I). The distribution of the three different clause types in the Mainland Scandinavian languages is shown in figure $1^{16}$.

A Loglinear Analysis of the data shows a significant interaction effect for the variables language (Danish, Norwegian, Swedish) and clause type (I, II, III), $p<0.01, \chi^{2}=308$ and $d f=$ 2. That is, the distribution of the three different clause types is significantly different in Danish, Norwegian and Swedish, which suggests different degrees of grammaticalization in the Mainland Scandinavian languages (see section 6). In all three languages, MAYBE occurs most frequently in V2 clauses (clause type II). Clause type I, which represents one of the older stages in MAYBE's development, is marginally attested in all languages. Clause type III is only productive in Swedish. The Norwegian and Danish samples contained no instances of this structure.

\footnotetext{
${ }^{16}$ The Swedish bar represents the results of $P 98$ and RII together.
} 


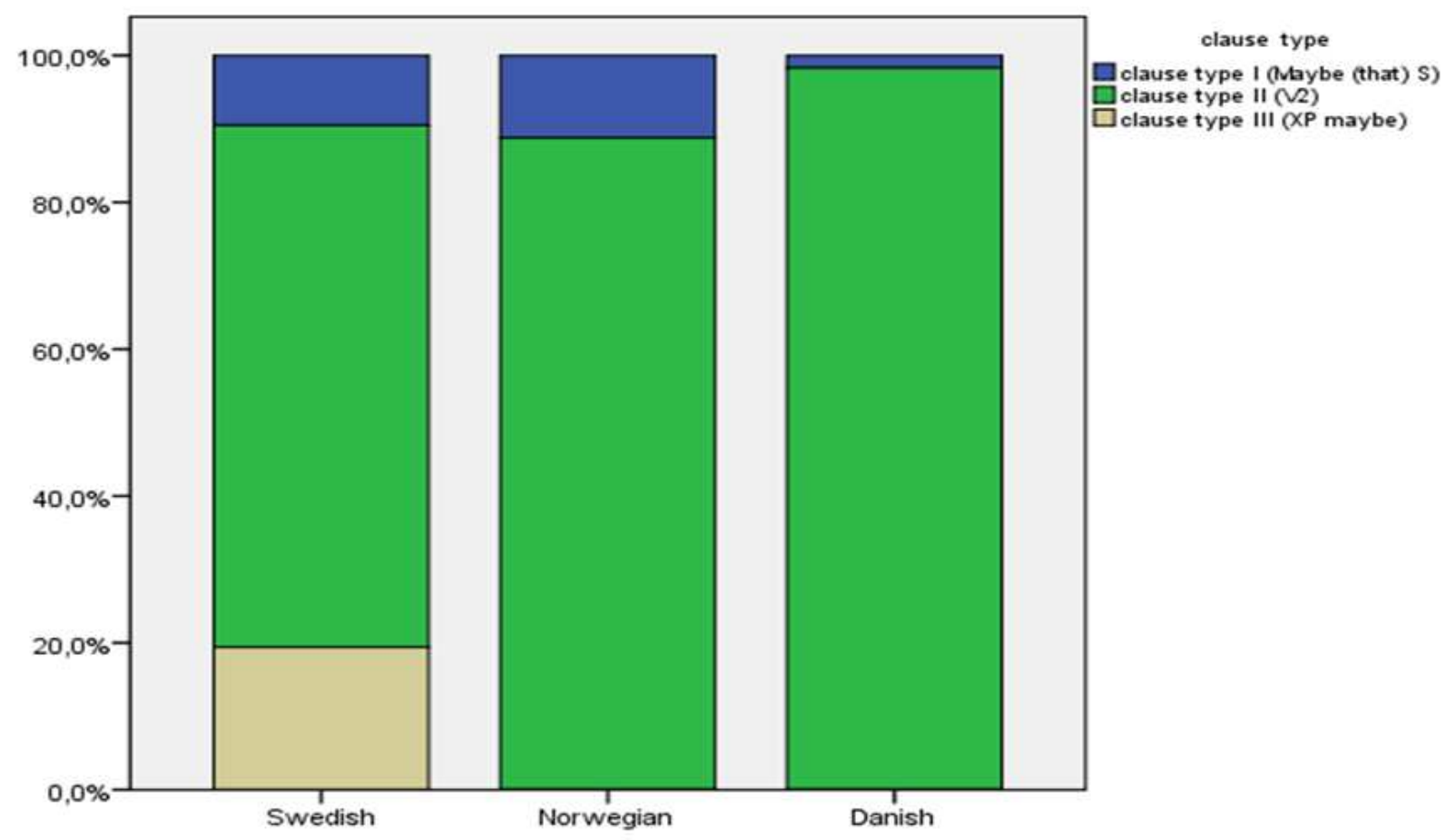

Figure 1. Bar chart of the distribution of clause type I, II and III in the Swedish, Norwegian and Danish random samples.

\subsection{Clause type I}

KS clauses are attested in Norwegian, Danish and Swedish, but this non-V2 structure is far less frequent than the standard V2 clauses. KS clauses form $9.5 \%$ of the Swedish, $11.3 \%$ of the Norwegian and only $1.7 \%$ of the Danish MAYBE clauses. No occurrences of KaS clauses are attested in the Norwegian, Swedish and Danish random samples. This does not mean that this clause type has disappeared from the language, but rather that it is on its way of becoming obsolete. Separate searches result in sporadic examples (16b). Examples of KS and KaS clauses are given in (16). The percentages for the subtypes of clause type I, KS and KaS clauses, are given in table 1.

Kanske han också haft en arbetsam dag. Swedish Maybe he also had-pRF a hard-working day. RII 'Maybe he also had a tough day.'

KS Kanskje jeg kan omformulere spфrsmålet.

Norwegian Maybe I can reformulate question-the. 'Maybe I can reformulate the question.'

Norsk Aviskorpus KS
Danish KorpusDK en form for falles administration.
a form for common administration. 'Maybe the parties can come to an agreement on some kind of joint administration.' 
b. KaS Kanske att förbannelsen ännu inte är hävd. Swedish Maybe that curse-the yet not is maintained. RII

'Maybe the curse is not yet at work.'

KaS Kanskje at det ikke er så mye som skjer Norwegian

Maybe that it not is so much that happens Norsk

$i$ byen.

Aviskorpus

in town-the.

'Maybe there is not much going on in town.'

$\mathrm{KaS}$ Måske at jeg kunne have afbrudt dem. Danish

Maybe that I could have stopped them. KorpusDK

'Maybe I could have stopped them.'

Table 1. Percentages for the subtypes of clause type I in the Swedish, Norwegian and Danish random samples.

\begin{tabular}{|l|l|l|l|l|}
\hline subtype & $P 98$ & RII & $\begin{array}{l}\text { Norsk } \\
\text { Aviskorpus }\end{array}$ & KorpusDK \\
\hline KS clause & $7.0 \%$ & $12.0 \%$ & $11.2 \%$ & $1.7 \%$ \\
\hline KaS clause & $0.1 \% *$ & $0.5 \% *$ & $0.02 \% *$ & $0.0 \% *^{* 17}$ \\
\hline
\end{tabular}

* Total number of occurrences of KaS divided by the total number of occurrences of MAYBE in the entire corpus.

\subsection{Clause type II}

Clauses in which MAYBE is preceded by the subject and finite verb are very frequent. This comes as no surprise since Mainland Scandinavian languages are V2 languages and this clause type adheres to the V2 principle. SF clauses are most frequent in Norwegian. In Swedish and Danish, SF clauses come in second place. Examples of SF, KF, OF and AF clauses are given in (18-21). The percentages for the subtypes of clause type II, SF, KF, OF and AF clauses, are given in table 2.
a. SF
Man är kanske
rädd att barnen inte ska
scared that children not shall
One is maybe scared that children
lära sig svenska ordentlig.
learn themselves Swedish properly.
'Maybe they are afraid that the children do not acquire the
Swedish language properly.'
b. SF Jeg har kanskje gjort det motsatte, sier Gashi.
I have maybe done the opposite, says Gashi.
'Maybe I have done the opposite, says Gashi.'
c. SF Han er måske lidt på den gamle side-over 60 .
$\mathrm{He}$ is maybe little on the old side - over 60.
'He is maybe a little bit too old - over 60 years of age.'

Swedish

Norwegian

Norsk

Aviskorpus

Danish

KorpusDK

\footnotetext{
${ }^{17}$ Only two occurrences in the entire corpus.
} 
Like SF clauses, KF clauses are V2 clauses. In Swedish and Danish this structure is most frequent of all MAYBE clauses. For Norwegian this structure comes in second place.
a. $\mathrm{KF}$
Kanske är det för
att jag är
ir svart, jag vet inte. Swedish Maybe is it because that I am black, I know not. $P 98$ 'Maybe it is because I am black, I do not know.'
b. KF Kanskje kommer mellom 5000 og 10.000 tilskuere. Maybe come between 5000 and 10.000 spectators. 'Maybe there will be between 5000 and 10.000 people.'
Norwegian
Norsk
Måske får du et tilbud fra Copenhagen Models,
Aviskorpus
c. $\mathrm{KF}$ Maybe get you an offer from Copenhagen Models,
fnisede Marianne og så lidt misundelig ud.
chuckled Marianne and looked little jealous out. chuckled Marianne and looked little jealous out.
'Maybe you will get an offer from Copenhagen Models, chuckled Marianne and she looked a bit jealous.'
Danish
KorpusDK

OF clauses, i.e. clauses with a fronted object or predicate complement are far less frequent than KF and SF clauses in all three languages.
a. $\mathrm{OF}$
Plågorna kan man kanske lindra något.
Swedish
Plagues-the can one maybe relieve little.
RII
'One can maybe relieve the plagues a little.'
b. $\mathrm{OF}$
Organene han fikk operert inn var kanskje
Organs-the he got operated in were maybe
Norwegian
de som fungerte best.
Norsk
those that functioned best.
Aviskorpus
'The organs he was operated on were maybe those that functioned best.'
c. OF Dem kan vi med vores viden måske hjalpe
Them can we with our knowledge maybe help
til at kompe videre.
with to fight further.
'With our knowledge we can maybe help them to keep on fighting.'
Danish

Also AF clauses i.e. clauses with fronted adverbials are less frequent than KF and SF clauses.
$\begin{array}{llll}\text { a. } & \mathrm{AF} & \mathrm{Nu} \text { blir jag } & \text { kanske avstängd nästa } \\ & \text { Now become I maybe suspended next }\end{array}$
Swedish
match, säger Matti
match, says Matti.
P98
'Maybe I will now be suspended the next match, says Matti'
b. AF Onsdag får jeg kanskje begynne å trene lett igjen.
Norwegian
Wednesday get I maybe begin to train easy again.
Norsk
'On Wednesday maybe I can start training lightly again.'
Aviskorpus
c. AF Før eller siden får vi måske at vide, hvad der
Danish
Sooner or later get we maybe to know, what there
KorpusDK
virkelig skete $i$ computer-rummet på USS Vincennes.
really happened in computer room-the at USS Vincennes.
'Sooner or later we might get to know what really happened in the computer room at USS Vincennes.' 
Table 2. Percentages for the subtypes of clause type II in the Swedish, Norwegian and Danish random samples.

\begin{tabular}{|l|c|l|l|l|}
\hline subtype & $P 98$ & $R I I$ & $\begin{array}{l}\text { Norsk } \\
\text { Aviskorpus }\end{array}$ & KorpusDK \\
\hline SF clause & $23 \%$ & $22 \%$ & $43.6 \%$ & $33.6 \%$ \\
\hline KF clause & $36 \%$ & $37 \%$ & $30.2 \%$ & $42.7 \%$ \\
\hline OF clause & $2 \%$ & $2 \%$ & $3 \%$ & $4 \%$ \\
\hline AF clause & $13 \%$ & $8 \%$ & $12 \%$ & $18 \%$ \\
\hline
\end{tabular}

\subsection{Clause type III}

A striking difference between Swedish on the one hand and Norwegian and Danish on the other hand, is that $\mathrm{OK}, \mathrm{AK}$, and SK clauses are all part of the Swedish random sample whereas they are not attested in the Norwegian and Danish random samples. These clauses are also not mentioned in standard grammars of Norwegian and Danish, Norsk Referanse Grammatikk (1997) and Dansk Grammatik (2005) respectively. A separate search for these subtypes results in a few Norwegian examples (only SK and AK clauses), but no Danish examples. Hence, unattested clause types are not necessarily nonexistent but they may occur very rarely. Examples of SK, OK and AK clauses are given in (22). The percentages for the subtypes of clause type III, SK, OK and AK clauses are given in table 3.

(22) a. SK Hon kanske inte alls känner igen mej, säger hon tyst. Swedish She maybe not all recognize again me, says she softly. RII 'Maybe she does not recognize me at all, she says softly.'

b. SK Han kanskje skadet seg da han falt,

Norwegian $\mathrm{He}$ maybe hurt himself when he fell var tiltalets forklaring på hvordan Kildebo was suspect-the's statement of how Kildebo Norsk havnet bevisstlos og sterkt forslätt $i$ veibanen. ended unconscious and strongly beaten in road-the. 'Maybe he hurt himself when he fell, was the suspect's statement of how Kildebo ended up unconscious and strongly beaten up on the road.'

c. OK Och helt ogrundade kanske inte

Swedish

And completely unfounded maybe not P98 de misstankarna är. these suspicions are.

'These suspicions are maybe not completely unfounded.'

d. AK När någon av våra idéer bliver verklighet When one of our ideas become reality kanske inte vi går på skolan längre. maybe not we go on school-the longer. 'If one of our ideas come true, we might not be going to school any longer.'

e. AK Da kanskje du blir litt mer popular.

Norwegian Then maybe you become bit more popular. Norsk 'Then you might become a little more popular.'

Aviskorpus 
Table 3. Percentages for the subtypes of clause type III in the Swedish, Norwegian and Danish random samples.

\begin{tabular}{|l|c|l|l|l|}
\hline subtype & $P 98$ & RII & $\begin{array}{l}\text { Norsk } \\
\text { Aviskorpus }\end{array}$ & KorpusDK \\
\hline SK clause & $11 \%$ & $18 \%$ & $0 \%$ & $0 \%$ \\
\hline OK clause & $2 \%$ & $0 \%$ & $0 \%$ & $0 \%$ \\
\hline AK clause & $7 \%$ & $1 \%$ & $0 \%$ & $0 \%$ \\
\hline
\end{tabular}

The status of AK, OK and SK clauses is unclear because these clauses suddenly emerged in literary language use. Especially SK clauses are very frequent in the work of the Swedish writer August Strindberg (1849-1912), whereas they were very infrequent in the period just before and after his work was published (Andréasson 2002, 32). Nowadays, this clause type is well established in Swedish, 9.5\% of the declarative main clauses, but extremely rare in Norwegian and possibly nonexistent Danish. More research on the status of clause type III is needed to find out whether its development is a case of grammaticalization (split or divergence), i.e. a 'natural' development, or coinage (invention of a new structure) by Strindberg, see section 6 .

\section{The grammaticalization of MAYBE}

Grammaticalization is a gradual diachronic process of language change that "refers most especially to the steps whereby particular items become more grammatical through time" (Hopper and Traugott 2003, 2). It is part of a "wider linguistic phenomenon of structuration, through which combinations of forms may in time come to be fixed in certain functions"(ibid.). The order in which these transitions tend to occur is called a 'cline' or 'pathway' of change. Grammaticalizing items can be located at different clustering points along a cline, representing variant degrees of grammaticalization.

The coexistence of adverbial (clause type II) and subordinating kanske (clause type I and III) has given rise to the assumption that there are separate grammaticalization paths for the different syntactic variants of kanske (Lundin 1997; Andréasson 2002, 36). Andréasson distinguishes two types of kanske; one type that behaves just like other sentence adverbs (V2 clauses), and one type that has preserved the older subordinating function of the verb phrase 'it can / may happen that' followed by a subordinate clause (all non-V2 clauses). Hence, one grammaticalization process has led to adverbial kanske and another parallel grammaticalization process has resulted in kanske with subordinating properties. According to her, both grammaticalization processes are completed by now (ibid, 41).

In what follows I will argue that it is more plausible that the three different syntactic variants represent different stages in a single grammaticalization pathway from subordinating verb phrase into epistemic adverb. I will illustrate this by means of syntactic, morphological and semantic changes that can be observed in the development of kanske.

Hopper $(1991,22)$ mentions five principles that can be used as heuristic devices to identify potential cases of grammaticalization. These principles are layering, divergence, specialization, persistence and decategorialization. The first principle, layering, provides a good explanation for the coexistence of adverbial and subordinating MAYBE. Layering, or synchronic variation, is the phenomenon that a word or construction gets another meaning or function besides the meaning or function it already has. In this case, MAYBE gets an adverbial function besides the subordinating properties it already has. The older MAYBE with subordinating properties still exists along with the newer MAYBE that functions as pure 
sentence adverb. The new layer (clause type II) gradually replaces the older layer (clause type I):

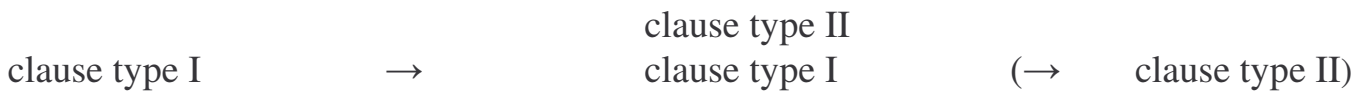

Completed grammaticalization for MAYBE would mean that it only occurs as pure sentence adverb in V2 clauses, which is not yet the case but Danish is getting close, see figure 1. It is the tendency, but it should be noted that grammaticalization is by no means deterministic. Changes do not have to occur and if a change takes place it does not have to go through all transition stages along the cline (Hopper and Traugott 2003, 130-1). Therefore clause type II as the final stage of the grammaticalization of MAYBE is put into brackets. Adverbial MAYBE is the most grammaticalized variant because it has lost the original subordinating properties and functions as an epistemic marker of possibility.

Clause type III is a productive structure in Swedish but extremely rare in Danish and Norwegian. This can be explained by Hopper's second principle of divergence. Divergence or split, a subtype of layering, is the phenomenon that an older layer can undergo a new grammaticalization process. That is, a new layer is formed out of an older layer. This principle is only relevant in the development of MAYBE if the new variant of subordinating MAYBE (clause type III) is not an instance of coinage. This clause type first emerges in literary and poetic texts, and is especially very frequent in the work of August Strindberg who might have introduced this structure to a large audience. If the rise of this clause type is a 'natural' development than it forms a new layer out of the original verb phrase or $\mathrm{K}(\mathrm{a}) \mathrm{S}$ clauses, see also section 4.3. Note that this clause type is not an intermediate stadium because both subordinating and adverbial MAYBE already existed before this clause type came into being.

$$
\begin{array}{lll}
\text { clause type I } \rightarrow \quad \begin{array}{l}
\text { clause type II } \\
\text { clause type I } \\
\text { L clause type III }
\end{array} \quad \rightarrow \quad \text { (clause type II) }
\end{array}
$$

Syntactic fixation (cf. Lehmann 1995) is a characteristic related to layering and divergence and a useful criterion in determining the degree of grammaticalization. Since grammaticalization generally involves syntactic fixation, a decrease in syntactic freedom would imply advanced grammaticalization of MAYBE. But first, the transition from subordinating MAYBE to adverbial MAYBE results in more syntactic variation because MAYBE can occur in positions in which it is followed by subordinate word order and in positions for sentence adverbs. In Swedish there are more syntactic positions available than in Danish and Norwegian, one of which is the place of the finite verb. For Norwegian and Danish it is unclear if OK, AK and SK clauses ever existed to the same extent as in Swedish, separate searches may reveal sporadic examples. As can be seen from figure 1, MAYBE functions almost solely as sentence adverb in Danish and Norwegian. In Swedish, clause type III is productive, but V2 clauses are also most common in Swedish. The syntactic freedom of MAYBE is decreasing because positions for sentence adverbs become more fixed and occurrences of the oldest structure (clause type I) are decreasing in all three languages. MAYBE is more grammaticalized in Norwegian and Danish (=less syntactic freedom, more V2 clauses) than in Swedish (=more syntactic freedom, more non-V2 clauses). That is, MAYBE is at different stages of grammaticalization in the Mainland Scandinavian languages.

The grammaticalization of MAYBE is accompanied by increasing productivity and frequency. "Over time grammatical items come to be more frequent than the lexical constructions from which they derive, that is, they become more token frequent than their source" (Brinton and Traugott 2005, 29, 109). MAYBE is one of the most frequent epistemic 
adverbs in Mainland Scandinavian and the original verb phrase (det) kan ske (att) and the older non-V2 structures are far less frequent now. Grammaticalizing items become more productive in the sense that they occur with increasingly large numbers of categories or constructions (type frequency). "The shift is from a less to more productive pattern, see Lehmann's 'paradigmaticization' and Himmelmann's 'host-class expansion'” (ibid, 109). On its way from verb phrase to sentence adverb, MAYBE enters the adverbial paradigm (the hostclass) which is a more productive class than the verb phrase from which it derives. Adverbial positions and functions are extended the more MAYBE grammaticalizes. Nowadays MAYBE occurs most frequently as sentence adverb in V2 clauses. Besides being a sentence adverb, MAYBE can also be a modifying adverb (cf. footnote 8 ) or a speech-act adverb ${ }^{18}$.

The third principle that is related to MAYBE is specialization. That is, many similar and simultaneous existing expressions are reduced to one major expression. When MAYBE was not yet an univerbated adverb, other modal forms could be used as alternating forms for kan, for example må 'may' or tör 'must'. The main verb ske 'happen' could alternate with hända 'happen' and other words like for example the modal particle väl 'well' could be inserted between the modal form and the main verb. Inflection for tense was also possible in the older stages of development. Examples (25a, b, c) are taken from Andréasson (2002, 20$1)$.

a. Iak bidher thet gärna, o thet ma ske, at iak matte the frwgho se I pray it gladly, o it may happen, that I may the lady see 'I pray gladly, o may it happen, that I may see the lady.'

b. Kan thz swa hända at nakor aff bradho modhe

Can it so happen that someone of hurried mood

[...] talar hastelika möte androm.

[...] speaks hastily to others

'It may very well happen that someone (who is) in a hurry [...] speaks hastily to others.'

c. thy kan thz wäll saa skee thz noghrom wardher wee. because can it well so happen it someone $_{- \text {DAT }}$ becomes pain. 'Because it may well happen that it hurts someone.'

Out of these options the synonymous adverbs måhända, törhända and måhända were formed. Kanske is by far the most frequent epistemic adverb of the MAYBE-type in Swedish (5913 hits in $P 98$ and 5183 hits in RII), kanhända and måhända occur less frequently (respectively 23 and 92 hits in $P 98,52$ and 85 hits in $R I I)$ and törhända is archaic but may be used in literary texts ( 1 hit in $P 98$ and 35 hits in RII). Danish and Norwegian counterparts of måhända and törhända are not found in KorpusDK and Norsk Aviskorpus. The counterpart of kanhända in Danish and Norwegian can be written as one or two words, both forms are correct. Univerbated kanhoende occurs 4 times in KorpusDK and kanhende occurs 55 times in Norsk Aviskorpus. The non-univerbated form kan hoende occurs 57 times in KorpusDK and kan hende 5198 times in Norsk Aviskorpus ${ }^{19}$.

Persistence is the fourth principle that applies to MAYBE. This relates to the observation that a new word or function retains traces of the original word or function from which it emerged. MAYBE still has the subordinating properties of the original verb phrase (det) kan ske (att) in clause type I and III.

The fifth and last principle is decategorialization. This means that the new word or function has lost (all) the grammatical properties of the original word or function from which

\footnotetext{
${ }^{18}$ For example: Kan du kanske hjälpa mig? 'Can you maybe help me?'

${ }^{19}$ These numbers include combinations of modal auxiliaries and main verbs with referential subject.
} 
it emerged. In the case of MAYBE, inflection and insertion of words between kan and ske is no longer possible, cf. *kundeske 'couldhappen', *kan väl ske 'can / may well happen'. Furthermore, the development of MAYBE contains a shift in category, from verb phrase to adverb.

Apart from Hopper's principles, other aspects of the history of Mainland Scandinavian MAYBE suggest that this is a case of grammaticalization as well. The first is its typological generality, i.e. "the phenomenon that grammaticalization patterns tend to be crosslinguistically replicated and may affect whole semantic classes" (Brinton and Traugott 2005, 109; cf. also Bybee et.al. 1994; Heine and Kuteva 2002). There are many epistemic adverbs with a similar structure ('can' / 'may' + 'happen' / 'be') in other European languages which suggests that the univerbation of a modal form 'can' or 'may' and a main verb meaning 'happen' has been a process of productive word formation in various languages.

Univerbation, which is accompanied by phonetic reduction, is also relevant with regard to the merger of a verb phrase into an adverb: (det) kan ske (att) $\rightarrow$ kanske. In Norwegian and Swedish, but not in Danish, there is a shift in stress. Kansk(j)e has stress on $k a n$ but no stress on $s k(j) e$. Måske takes stress on ske. In case of univerbation the original prosodic structure is lost. The original verb phrase accentuation (kan'ske) changed into compound accentuation ('kanske). At the beginning of the 19th century kanske could be pronounced in both ways. In the middle of the 19th century it is only mentioned with compound accentuation in dictionaries but in SAOB it is written that it is possible to pronounce kanske with verb phrase accentuation, for example in poetry (Andréasson 2002, 37).

Another process that is related to the grammaticalization of MAYBE is semantic bleaching or desemantication. This means "gradual weakening of meaning through generalization, most especially loss of contentful meaning. Items that grammaticalize tend to have quite general meanings" (Brinton and Traugott 2005, 108). The term bleaching is somewhat misleading because there is loss of original, lexical meaning but gain of a more general and abstract meaning. In the case of MAYBE it can be observed that the function / meaning of ske 'happen' is no longer relevant in the meaning of the adverb. The meaning has changed from 'can / may happen' into the more general 'can / may be'.

The last process to be mentioned here is subjectification. That is "[...] the development of a grammatically identifiable expression of speaker belief or speaker attitude to what is said" (Traugott 1995, 32). With regard to MAYBE there is a development from an objective, declarative predicate that states that something may happen to an adverb that expresses the speaker's subjective evaluation of the likelihood of the predicate. ${ }^{20}$

\footnotetext{
${ }^{20}$ Some of the above mentioned principles are also characteristics of lexicalization, especially processes related to univerbation and change of meaning, i.e. "the change whereby in certain linguistic contexts speakers use a syntactic construction or word formation as a new contentful form with formal and semantic properties that are not completely derivable or predictable from the constituents of the construction or the word formation pattern. Over time there may be further loss of internal constituency and the item may become more lexical." (Brinton and Traugott 2005, 96). See Beijering and Norde (in prep.) for a discussion of the grammaticalizationlexicalization interface for Mainland Scandinavian MAYBE.
} 


\title{
8. Conclusion
}

The epistemic adverb MAYBE developed out of the non-fixed lexical expression meaning 'it can/may happen that' into a marker of epistemic possibility. The coexistence of kanske with and kanske without subordinating properties represents different stages of grammaticalization on the way from verb phrase to epistemic adverb instead of separate grammaticalization processes resulting in different syntactic variants as suggested by Andréasson $(2002,46)$ and Lundin (1997).

The results of the case studies indicate that MAYBE is less grammaticalized in Swedish than in Norwegian and Danish. This is reflected by the degree of multipositionality of MAYBE. The distribution of the three different clause types is significantly different in the Mainland Scandinavian languages, see figure 1. In Swedish there are more syntactic positions available than in Danish and Norwegian, one of which is the place of the finite verb.The reason why Swedish kanske can occupy the position of the finite is most likely due to the fact that it belongs to the class of clausal words and thus has preserved verbal properties. For Norwegian and Danish it is unclear if clause type III ever existed to the same extent as in Swedish. Closer scrutiny of the status of SK, OK and AK clauses will make clear whether this is a case of divergence or split (grammaticalization) or coinage, i.e. invention and introduction of a new clause type in the language.

All in all, MAYBE functions more and more as pure sentence adverb and occurs most frequently in V2 clauses in the Mainland Scandinavian languages. MAYBE is losing its subordinating properties and non-V2 clauses are gradually being replaced by V2 clauses in which MAYBE functions as pure sentence adverb.

\author{
Abbreviations \\ 3SG third person singular \\ DAT dative \\ PRF perfect
}

\section{References}

Andréasson, M. 2002. Kanske- en vilde i satsschemat. (=Meddelanden från Institutionen för svenska språket 41). Göteborg: Institutionen för Svenska Språket.

Beijering, K., and M. Norde. in prep. Epistemic adverbs at the interface of grammaticalization and lexicalization.

Brinton, L.J., and E. C. Traugott. 2005. Lexicalization and Language Change. Cambridge: Cambridge University Press.

Bybee, J., R. Perkins, and W. Pagliuca. 1994. The Evolution of Grammar: Tense, Aspect, and Modality in the Languages of the World. Chicago: University of Chicago Press.

Diderichsen, P. 1946. Elementoer Dansk Grammatik. Copenhagen: Gydendal.

Faarlund, J. T., S. Lie, and K. I. Vannebo. 1997. Norsk referansegrammatikk. Oslo: Universitetsforlaget

Heine, B., and T. Kuteva. 2002. World lexicon of grammaticalization. Cambridge: Cambridge University Press.

Hellquist, E. 1939. Svensk etymologisk ordbok. Lund.

Holmberg, A., and C. Platzack.1995. The role of inflection in Scandinavian syntax. New York: Oxford University Press.

Hopper, P. J. 1991. On some principles of grammaticalization. In Traugott, E. C., and B. Heine (eds) Approaches to grammaticalization, 2 vols, 17-35. Amsterdam / Philadelphia: John Benjamins Publishing Company. 
Hopper, P. J., and E. C. Traugott. 2003. Grammaticalization. 2nd ed. Cambridge: Cambridge University Press.

Lehmann, C. 1995. Thoughts on grammaticalization. München: LINCOM Europa.

Lindqvist, A. M. 1961. Satzwörter: eine vergleichende syntaktische Studie. (=Göteborgs universitetets årsskrift 97). Göteborg: Göteborgs universitet.

Lundin, K. 1997. Från verbkombination till adverb. Unpublished paper, University of Lund.

Ordbog over det danske sprog. http://ordnet.dk/oods

Platzack, C. 1998. Svenskans inre grammatik - det minimalistiska programmet. En introduktion till modern generativ grammatik. Lund: Studentlitteratur.

Platzack, C. 1999. Review of Norsk referansegrammatikk. Maal og Minne (1): 91-108.

Ramat, P., and D. Ricca. 1998. Sentence adverbs in the languages of Europe. In van der Auwera, J., and D. P. Ó. Baoill (eds) Adverbial constructions in the languages of Europe, 187-273. Berlin / New York: Mouton de Gruyter.

Svenska akademiens ordbok. http://g3.spraakdata.gu.se/saob/

Teleman, U. 1974. Manual för grammatisk beskrivning av talad och skriven svenska. Lund: Studentlitteratur.

Teleman, U., S. Hellberg, and E. Andersson. 1999. Svenska Akademiens Grammatik IV: Satser och meningar. Stockholm: Norstedts.

Traugott, E. C. 1995. Subjectification in grammaticalisation. In Stein, D. and S. Wright (eds) Subjectivity and subjectivisation, 31-54. Cambridge: Cambridge University Press.

Vikner, S. 1995. Verb Movement and Expletive Subjects in the Germanic languages. New York: Oxford University Press.

Wessén, Elias. 1968. Ett fornsvenskt vardagsord Fsv. maxan - da. måske - sv. kanske. Nysvenska Studier 47. Lund: Carl Bloms Boktryckeri A.-B.

Zola Christensen, R., and L. Christensen. 2005. Dansk grammatik. Odense: Syddansk Universitetsforlag. 